
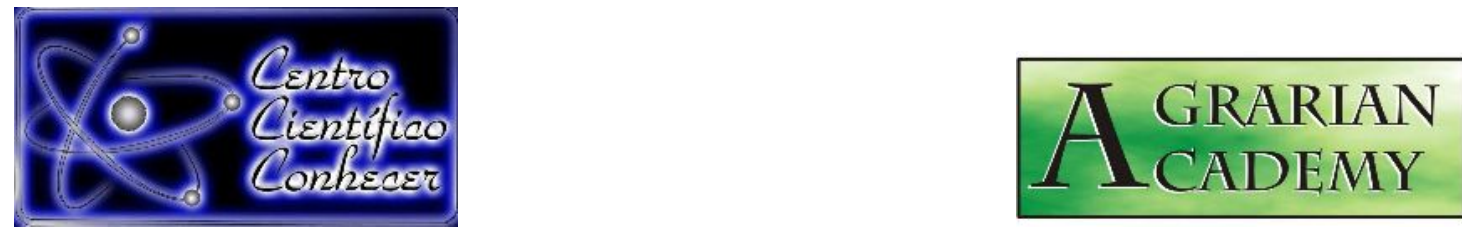

\title{
OTIMIZAÇÃO DO DIAGNÓSTICO MOLECULAR DO VÍRUS DA LEUCOSE AVIÁRIA SUBGRUPO - J (VLA - J)
}

\footnotetext{
Renato Luís Luciano ${ }^{{ }^{*}}$, Paulo Lourenço da Siva ${ }^{2}$

${ }^{1}$ Instituto Biológico. Centro Avançado de Pesquisa Avícola. Rua Bezerra Paes, 2278, 13690-000. Descalvado, SP, Brasil. E-mail: rluciano@biologico.sp.gov.br

${ }^{2}$ Departamento de Medicina Animal. Faculdade de Medicina Veterinária.

Universidade Federal de Uberlândia. Av. Pará, 1720, Bloco 2T, 38400-902.

Uberlândia, MG. Brasil.

Recebido em: 02/06/2019 - Aprovado em: 15/06/2019 - Publicado em: 22/07/2019

DOI: 10.18677/Agrarian_Academy_2019a22
}

\begin{abstract}
RESUMO
O vírus da leucose aviária (VLA) é um retrovírus responsável pelo desenvolvimento da leucose linfóide, mielóide e eritróide em aves que apresenta diferentes subgrupos ( $A, B, C, D, E$ e J) classificados de acordo com as variações antigênicas do envelope glicoproteico. O vírus da leucose aviária subgrupo J (VLA-J) encontra-se associado com a ocorrência de leucose mielóide em reprodutoras pesadas e frangos de corte, acarretando inúmeros prejuízos para a indústria avícola. As condições para o diagnóstico molecular baseado na reação em cadeia da polimerase (PCR) e na reação de transcrição reversa associada a PCR (RT-PCR) foram otimizadas utilizando-se amostras de tumores (provenientes do baço, fígado e osso esterno), hastes de pena e swabs cloacais provenientes de reprodutoras pesadas e frangos de corte, a fim de verificar qual o melhor método para a detecção viral do VLA-J. Os parâmetros das reações foram otimizados à partir dos protocolos de extração de DNA descritos por Smith et al. (1998) e Saraiva (1999). O protocolo descrito por Smith et al. (1998) foi o melhor método de extração tanto de DNA quanto de RNA nas amostras tumorais de esterno. A técnica de PCR demonstrou ser um método rápido, prático e sensível o qual pode ser utilizado nos programas de erradicação e controle da leucose aviária nos plantéis avícolas.
\end{abstract}

PALAVRAS-CHAVE: leucose mielóide, PCR, RT-PCR, vírus da leucose aviária, VLA-J

\section{OPTIMIZATION OF THE MOLECULAR DIAGNOSTIC TO AVIAN LEUKOSIS VIRUS SUBGROUP $\mathrm{J}(\mathrm{ALV}-\mathrm{J})$}

\footnotetext{
ABSTRACT

Avian leukosis virus (ALV) is a retrovirus responsible to development of avian lymphoid leukosis, myeloid leucosis and erythroid with different subgroups (A, B, C, $D, E$ and $J$ ), classified according the glycoproteic antigenic variations of the glycoprotein envelope. Avian leukosis virus subgroup $\mathrm{J}$ (ALV-J) is associated with AGRARIAN ACADEMY, Centro Científico Conhecer - Goiânia, v.6, n.11; p. 227 
occurrence of the myeloid leukosis in heavy breeders and chickens, causing several losses to poultry industry. Molecular diagnostic conditions based in polymerase chain reaction (PCR) and reverse transcription associate to PCR (RT-PCR) were optimized using tumor samples (from spleen, liver and sternal bone), feather pulp and cloacal swabs collected from heavy breeders and chicken in order to verify which is the best method to viral detection of the ALV-J. Reactions parameters were optimized based on extraction protocols describes by Smith et al. (1998) and Saraiva (1999). The protocol described by Smith et al. (1998) was the best method to DNA extraction as well as RNA to tumor and sternal samples. PCR was the rapid, practical and sensitive method which can be used in programs to eradication and control of the avian leukosis in poultry.

KEYWORDS: myeloid leukosis, PCR, RT-PCR, avian leukosis vírus, ALV-J

\section{INTRODUÇÃO}

Leucose aviária é um termo genérico, usado para designar doença neoplásica em aves, causada pela infecção por retrovírus indutores de tumores, não havendo especificação do tipo de tumor predominante ou o tipo do vírus envolvido (SMITH et al., 1998). É uma doença imunodepressora responsável pelo desenvolvimento de leucose linfóide, mielóide ou eritróide em aves, sendo causada por um retrovírus denominado vírus da leucose aviária (VLA), o qual possui diferentes subgrupos, atualmente classificados em A, B, C, D, E e J, cuja transmissão pode ser vertical e/ou horizontal (PAYNE; NAIR, 2012).

O vírus da leucose aviária (VLA) é um retrovírus que pertence ao gênero Alpharetrovirus, da família Retroviridae, apresentando como características principais: pleomorfismo, forma esférica e envelope de 80-100 nm de diâmetro. As projeções do envelope são pequenas, pontiagudas e dispersas por toda a superfície, tornando-a rugosa. Possui nucleocapsídeos isométricos e esféricos e núcleo concêntrico. O vírion contém uma molécula linear de RNA de cadeia simples (PAYNE;NAIR, 2012; ICTV, 2017). Os vírus desta família são caracterizados por possuir a enzima transcriptase reversa (reverse transcriptase - sigla em inglês, RT), responsável pela síntese do DNA proviral à partir do RNA viral, como parte do mecanismo de replicação viral (PAYNE; NAIR, 2012).

As técnicas de diagnóstico molecular foram amplamente descritas, abrangendo PCR, RT-PCR, real time PCR e associações em reações imunoenzimáticas (DENG et al., 2010; OTTIGER, 2010; WANG et al., 2012; YUN et al., 2013; DAl et al., 2015; QIAN et al., 2015). A técnica de PCR-multiplex também foi padronizada para rápida diferenciação entre os subgrupos do VLA (GOPAL et al., 2012; GAO et al., 2014).

O diagnóstico molecular para detecção do VLA também foi desenvolvido para verificar a contaminação de vacinas produzidas em ovos embrionados e cultivos celulares derivados de aves, sendo um teste rápido e específico, visando o controle de qualidade de vacinas (HÄUPTLI et al., 1997; SILVA et al., 2007; RAJABZADEH et al., 2010). No Brasil, o controle do VLA é realizado em lotes de aves produtoras de ovos SPF (livres de patógenos) e de aves produtoras de ovos controlados para produção de vacinas inativadas (BRASIL, 2007).

O VLA-J foi isolado em diversas amostras (sangue, soro, cultura de FEG, hastes de penas, mecônio de pintos de um dia e tumores). Zavala e colaboradores (2002) desenvolveram uma técnica de PCR para detecção do VLA-J a partir de haste de penas, com a vantagem de realizar o diagnóstico sem haver a necessidade de sacrifício das aves.

AGRARIAN ACADEMY, Centro Científico Conhecer - Goiânia, v.6, n.11; p. 228 2019 
O objetivo deste estudo foi otimizar as técnicas de diagnóstico molecular (PCR e RT-PCR) para o VLA-J em amostra de hastes de penas, swab cloacal e tumores de baço, fígado e esterno provenientes de reprodutoras pesadas e frangos de corte, com a finalidade de estabelecer um método de diagnóstico molecular rápido e sensível.

\section{MATERIAIS E MÉTODOS}

\section{Otimização da Extração de DNA}

Os materiais biológicos utilizados na otimização das extrações de DNA foram tumores de baço, esterno e fígado, hastes de penas e swabs cloacais de aves de diferentes linhagens, sexo e idades, coletadas aleatoriamente e provenientes de propriedades localizadas na região de Uberlândia-MG.

\section{Protocolos de extração de DNA}

Foi utilizado o protocolo de extração de DNA descrito por Smith et al. (1998), utilizando-se isotiocianato de guanidina $(4 \mathrm{M})$, citrato de sódio $(25 \mathrm{mM})$ e Sarcosil $1 \%$, com 3 ciclos de extração com solução de fenol-clorofórmio-álcool-isoamil (25:24:1). O DNA foi precipitado em acetato de amônio $(7,5 \mathrm{M})$ e isopropanol puro (à $4^{\circ} \mathrm{C}$ ), sendo lavado com isopropanol $60 \%$ e ressuspendido em Tris-EDTA (TE).

O outro protocolo utilizado foi o descrito por Saraiva (1999), com solução de Tris-EDTA-NaCl $(0,1 \mathrm{M}$ de NaCl, 1,0 mM de EDTA e 10,0 mM de Tris), $20 \mu \mathrm{l}$ de proteinase $\mathrm{K}(10 \mathrm{mg} / \mathrm{ml})$ e $20 \mu \mathrm{l}$ de SDS (10\%). O DNA foi extraído em presença de $\mathrm{NaCl}$ saturado e precipitado em etanol absoluto, sendo lavado com etanol $(70 \%)$ e ressuspendido em Tris-EDTA (TE).

Após a extração de DNA, as amostras foram submetidas a eletroforese em gel de agarose $0,8 \%$ na presença de um tampão TBE (solução $0,5 \times$ de Tris - Ácido Bórico - EDTA (etileno diamino ácido tetraacético), pH 8.3, durante 1 a 2 horas à 100 volts e o produto final foi submetido a coloração com brometo de etídio $(0.5 \mu \mathrm{g} /$ $\mathrm{ml}$ de gel).

\section{Otimização da técnica de PCR}

\section{A. Concentração dos reagentes}

A descrição dos reagentes utilizados na reação do PCR encontra-se no quadro 1.

\begin{tabular}{lc}
\multicolumn{3}{l}{ QUADRO 1 - Condições do PCR } \\
\hline REAGENTES & CONCENTRAÇÃO \\
\hline MgCl2 $(\mathrm{mM})$ & 1,5 \\
PRIMERS (pmoles) & 7,5 \\
dNTP $(\mu \mathrm{M})$ & 100,0 \\
Taq Pol $(\mathrm{U})$ & 1,0 \\
Tampão da Taq & $1 \mathrm{x}$ \\
Amostra - DNA $(\mu \mathrm{l})$ & 5,0 \\
$\mathrm{H}_{2} \mathrm{O}(\mu \mathrm{l})$ & 14,8 \\
\hline Vol. Total $(\mu \mathrm{l})$ & $\mathbf{2 5 , 0}$ \\
\hline
\end{tabular}




\section{B. Primers utilizados}

Os primers utilizados em todas as reações de PCR foram $\mathbf{H} 5$ e $\mathbf{H 7}$ que podem detectar mais precocemente isolamentos recentes do vírus, sendo mais úteis para diagnósticos do VLA-J em plantéis avícolas (SMITH et al., 1998). seguinte:

A seqüência dos oligonucelotídeos ou primers utilizada neste estudo foi a

H5: 5'GGATGAGGTGACTAAGAAAG 3'

H7: 5'CGAACCAAAGGTAACACACG 3'

Este par de primers foi derivado da sequência do HPRS-103 (acesso no Z46390 do Genbank), originando um produto amplificado de 545 pares de base (base pairs - sigla em inglês, bp) (SMITH et al., 1998).

\section{Programa do termociclador}

O programa utilizado no termociclador PTC-100 MJ Research, INC., encontrase no quadro 2.

QUADRO 2 - Programa do termociclador

\begin{tabular}{|c|c|c|c|}
\hline ETAPA & $\begin{array}{c}\text { № } \\
\text { CICLO(S) }\end{array}$ & TEMPERATURA $\left({ }^{\circ} \mathrm{C}\right)$ & TEMPO \\
\hline DESNATURAÇÃO & 01 & 95 & $5 \min$ \\
\hline DESNATURAÇÃO & \multirow{3}{*}{30} & 95 & $30 \mathrm{seg}$ \\
\hline ANELAMENTOO & & 58 & 30 seg \\
\hline EXTENSÃO & & 72 & 45 seg \\
\hline EXTENSÃO FINAL & 01 & 72 & $3 \mathrm{~min}$ \\
\hline
\end{tabular}

\section{Eletroforese em gel de agarose}

Após a reação de PCR, as amostras foram submetidas a eletroforese em gel de agarose $1,2 \%$ na presença de um tampão TBE (solução $0,5 \times$ de Tris - Ácido Bórico - EDTA (etileno diamino ácido tetraacético), pH 8.3, durante 1 a 2 horas à 100 volts e 0 produto final foi submetido a coloração com brometo de etídio $(0.5 \mu \mathrm{g} /$ $\mathrm{ml}$ de gel).

\section{E. Extração de DNA e RNA da amostra tumoral de esterno}

A amostra de tumor de esterno foi extraída segundo o protocolo descrito por Smith et al. (1998), sendo quantificada por espectrofotometria em uma densidade óptica (optical density - sigla em inglês, OD) de $260 \mathrm{~nm}$.

A partir da leitura obtida, calculou-se a concentração de DNA em ng/ $\mu \mathrm{l}$, através da seguinte fórmula:

$\mathbf{C}=\left(\mathbf{O D}_{260} \times \mathbf{F} \times 50\right)$ sendo:

C - a concentração de DNA (ng/ul);

$\mathbf{O D}_{260}$ - leitura obtida pelo espectrofotômetro, com densidade óptica de 260 $\mathrm{nm}$;

F - fator de diluição 
Foram realizadas várias diluições, afim de se obterem as seguintes quantidades de DNA da amostra de tumor de esterno: 250, 200,150, 100, 50 e 10 ng. Estas 6 amostras foram submetidas a PCR segundo as condições otimizadas.

\section{RESULTADOS}

\section{Resultados da otimização da extração de DNA}

A extração de DNA considerada padrão para as amostras tumorais foi a descrita por Smith et al. (1998). Para as amostras de hastes de penas (Figura 1) e swab cloacal não houve uma otimização adequada.

Embora o protocolo descrito por Saraiva (1999) seja empregado para extrair DNA, este foi eficaz para a extração de RNA das amostras tumorais, não sendo eficiente para a extração de DNA das amostras de swabs cloacais (Figura 2).

\section{Resultados da otimização da técnica de PCR}

As amostras de swab cloacal não apresentaram bandas específicas referentes ao produto amplificado, embora tenha sido identificado o vírus em uma única amostra.

As condições ideais da técnica de PCR para a amostra tumoral de esterno encontram-se no quadro 3.

QUADRO 3 - Condições do PCR para a amostra tumoral de esterno

\begin{tabular}{lc}
\hline REAGENTES & CONCENTRAÇÃO \\
\hline MgCl2 $(\mathrm{mM})$ & 1,5 \\
PRIMERS (pmoles) & 7,5 \\
dNTP $(\mu \mathrm{M})$ & 100,0 \\
Taq Pol $(\mathrm{U})$ & 1,0 \\
Tampão da Taq & $1 \mathrm{x}$ \\
DNA $(\mu \mathrm{l})$ & 3,0 \\
\hline Vol. Total $(\mu \mathrm{l})$ & $\mathbf{2 5 , 0}$ \\
\hline
\end{tabular}

\section{Resultados da extração de DNA e RNA da amostra tumoral de esterno}

\section{A. Resultado da quantificação do DNA por espectrofotometria} quadro 4.

O resultado da quantificação de DNA por espetrofotometria encontra-se no

QUADRO 4 - Resultado da quantificação do DNA por espectofotometria

\begin{tabular}{lc}
\hline AMOSTRA & Leitura Espectofotômetro $\left(\mathbf{O D}_{\mathbf{2 6 0}}\right)$ \\
\hline TUMOR DE ESTERNO & 0,2542 \\
\hline
\end{tabular}

\section{B. Resultado do cálculo da concentração do DNA}

A partir da leitura obtida no quadro 4 , calculou-se a concentração de DNA em $\mathrm{ng} / \mu \mathrm{l}$, segundo a fórmula descrita no item 4.4. O resultado desse cálculo encontra-se no quadro 5. 
QUADRO 5 - Concentração de DNA da amostra

\begin{tabular}{lc}
\hline AMOSTRA & Concentração de DNA (ng/ $/ \mathbf{l})$ \\
\hline TUMOR DE ESTERNO & 2542 \\
\hline
\end{tabular}

Os resultados indicaram que $317,75 \mathrm{ng}$ de DNA proveniente de tumor de esterno foram suficientes para amplificação de um produto específico. A partir deste valor, foi realizado o PCR das amostras submetidas a diluições equivalentes a 250, 200, 150, 100, 50 e $10 \mathrm{ng}$ (amostras 1, 2, 3, 4, 5, 6 e 7). As amostras 2, 3, 4, 5 e 7 apresentaram bandas específicas referentes ao produto amplificado, sendo que a amostra 6 não apresentou nenhuma banda (conforme mostra a Figura 3).

\section{Resultados das eletroforeses}

Os resultados das extrações de DNA e da técnica de PCR foram obtidos pela análise de géis de agarose $(0,8 \%$ e $1,2 \%)$ submetidos a eletroforose. No gel de agarose, as amostras foram consideradas positivas ou negativas conforme a presença ou não de bandas específicas (tanto para o DNA genômico, como para o produto amplificado da reação de PCR).

Os resultados das eletroforeses encontram-se nas figuras abaixo:

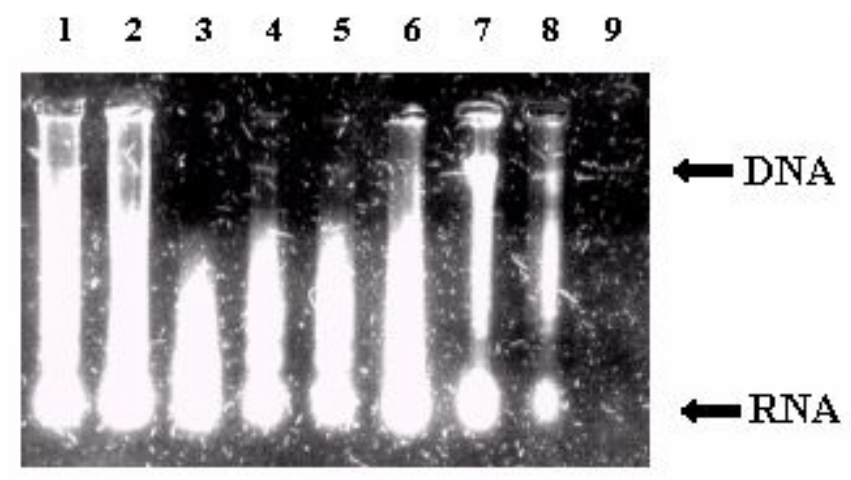

1. Tumor de baço (B1)

2. Tumor de baço (B1)

3. Tumor de baço (B2)

4. Tumor de fígado (F1)

5. Tumor de fígado (F2)

6. Tumor de fígado (F2)

7. Tumor de esterno (E1)

8. Tumor de esterno (E2)

9. Folículo de pena (P2)

FIGURA 1 - Resultado da eletroforese em gel de agarose $(0,8 \%)$ das amostras tumorais e de haste de pena submetidas a extração de DNA segundo protocolo descrito por Smith et al. (1998).

$\begin{array}{lllllllllllll}1 & 2 & 3 & 4 & 5 & 6 & 7 & 8 & 9 & 10 & 11 & 12 & 13\end{array}$

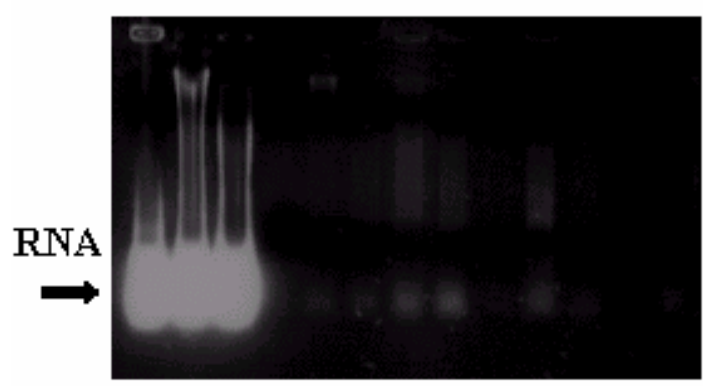

1. Tumor de baço

2. Tumor de fígado

9. Swab cloacal ave 6

3. Tumor de esterno

10. Swab cloacal ave 7

4. Swab cloacal ave 1 12. Swab cloacal ave 9

5. Swab cloacal ave 2 13.Swab cloacal ave 10

6. Swab cloacal ave 3

7. Swab cloacal ave 4

8. Swab cloacal ave 5

FIGURA 2 - Resultado da eletroforese em gel de agarose $(0,8 \%)$ das amostras tumorais e de swabs cloacais submetidas a extração de DNA segundo protocolo descrito por Saraiva (1999). 


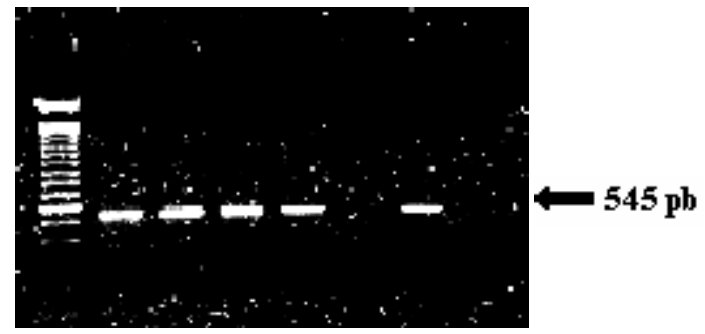

1. Marcador (peso molecular de $100 \mathrm{pb}$ )

2. Amostra $1(250 \mathrm{ng})$

3. Amostra 2 (200 $\mathrm{ng})$

4. Amostra $3(150 \mathrm{ng})$

5. Amostra 4 (100 $\mathrm{ng})$

6. Amostra 5 ( $50 \mathrm{ng})$

7. Amostra 6 ( $10 \mathrm{ng})$

8. Controle negativo

FIGURA 3 - Resultado da eletroforese em gel de agarose $(1,2 \%)$ dos produtos da PCR da amostra tumoral de esterno submetidas a extração de DNA e diluições

\section{DISCUSSÃO}

O passo anterior à reação de PCR consiste na extração de DNA e/ou RNA dos materiais utilizados (hastes de penas, tumores e swabs cloacais). Esta extração deve prevenir a ação de DNAses ou RNAses que degradam, respectivamente, o DNA ou RNA e eliminar ao máximo os inibidores da enzima polimerase (BRENTANO, 2000). A extração de DNA não foi possível nas amostras de swab cloacal (Figura 2, amostras $4-13$ ) devido a presença de contaminação com fezes, cujo crescimento bacteriano poderia produzir endonucleases (DNAses) que degradariam o DNA, além de outros inibidores da reação de PCR (RNAses e polimerases) tendo como resultado a ausência de bandas específicas referentes ao produto amplificado.

O SDS (sulfato dodecil de sódio) é um detergente que auxilia no processo de lise pela remoção de moléculas de lipídio e causa a ruptura da membrana celular (BROWN, 1990). Estes reagentes (EDTA, proteinase K e SDS) foram utilizados no protocolo descrito por Saraiva (1999).

Uma das possíveis causas para a obtenção de RNA a partir das amostras tumorais foi a baixa concentração de SDS e proteinase $\mathrm{K}$ utilizadas na extração, que não foi suficiente para romper a membrana nuclear das células, sendo o RNA proveniente do citoplasma das amostras da Figura 2.

Após a lise das células, o passo final da extração é a remoção dos debris celulares insolúveis. Os componentes, tais como frações da parede celular parcialmente digeridas podem ser peletizadas por centrifugação, deixando os demais componentes da extração celular, na fase superior (sobrenadante). $\mathrm{Na}$ extração de DNA, as células contêm quantidades significativas de proteína e RNA. Uma variedade de procedimentos pode ser usada para remover estes contaminantes, tornando o DNA purificado. O padrão de desproteinização da extração celular é a adição de fenol ou uma mistura de fenol:clorofórmio (1:1). Estes solventes orgânicos precipitam as proteínas, mas deixam os ácidos nucléicos (DNA/RNA) na fase aquosa da solução (sobrenadante) (BROWN, 1990), conforme o protocolo descrito por Smith et al. (1998) utilizado na Figura 1.

Em algumas extrações o conteúdo de proteínas foi tão grande, tornando-se necessário repetidas extrações com fenol:clorofórmio, mas deve-se considerar que cada extração com fenol:clorofórmio associada a sucessivas centrifugações produz uma certa quebra na estrutura da molécula de DNA (BROWN, 1990), fato este que foi observado na Figura-1 (amostras 1-8). 
Embora o protocolo utilizado nas amostras da Figura 2 tenha sido o descrito por Saraiva (1999) para a extração de DNA, houve a extração de RNA nos tumores (amostras 1-3), o que não ocorreu no swab cloacal (amostras 4-13), onde a concentração de proteinase $\mathrm{K}$ foi insuficiente para a extração de RNA.

Concentrações muito baixas de dNTP podem reduzir a quantidade de produto amplificado produzido (HOY, 1994), sendo que a concentração de todos os reagentes citados acima foi otimizada, de modo a amplificar um produto específico e característico (Figura 3). A amostra 6 da Figura 3 (com a concentração de DNA igual a $50 \mathrm{ng}$ ) não produziu uma banda específica devido a uma provável manipulação inadequada da referida amostra durante a eletroforese, sendo que tal fato é confirmado pela produção de uma banda específica de 545 pares de base (pb) da amostra correpondente a $10 \mathrm{ng}$ de concentração de DNA (amostra 7 da mesma figura).

\section{CONCLUSÕES}

Pelo exposto, pôde-se concluir que:

1. O protocolo descrito por Smith et al. (1998) foi o melhor método para a extração de DNA de amostras tumorais de esterno e posterior aplicação da técnica de PCR, sendo que este método também foi eficaz para a extração de RNA, possibilitando a realização de RT-PCR.

2. A técnica de PCR deve ser escolhida devido ao menor custo e menor complexidade quando comparada a RT-PCR.

3. A biópsia constituiu-se o material de escolha para a extração de DNA, utilizado como controle para a PCR.

4. Nas condições de realização deste experimento, as hastes de penas não se constituíram o material adequado para o diagnóstico do VLA-J, pois não foi possível a extração satisfatória de DNA deste material.

5. Altas concentrações de DNA podem produzir produtos não específicos ou inibir a reação de PCR.

\section{REFERENCIAS}

BRASIL. 2007. Ministério da Agricultura Pecuária e Abastecimento. Instrução normativa $n^{\circ} 56$, de 4 de dezembro de 2007. Estabelecer os procedimentos para registro, fiscalização e controle de estabelecimentos avícolas de reprodução e comerciais. Diário Oficial da União, Brasília, DF, 06 dez. 2007. Disponível em: < http://sistemasweb.agricultura.gov.br/sislegis/action/detalhaAto.do?method=visualiza rAtoPortalMapa\&chave $=1152449158>$.

BRENTANO, L. Biologia molecular e sua aplicação no diagnóstico de doenças das aves. In : ENCONTRO INTERNACIONAL DE CIÊNCIAS AVÍCOLAS, 4, 2000, Uberlândia. Anais ... Uberlândia : Departamento de Medicina Animal da Universidade Federal de Uberlândia, p. 28 - 48.2000. 
BROWN, T. A. Gene cloning : An introduction. 2. ed. London : Chapman \& Hall, p. $27-48,1990$.

DAI, M.; FENG, M.; LIU, D.; CAO, W.; LIAO, M. Development and application of SYBR Green I real-time PCR assay for the separate detection of subgroup J Avian leukosis virus and multiplex detection of avian leukosis virus subgroups $A$ and B. Virology journal, v. 12, n. 1, p. 52, 2015. Disponível em: < https://virologyj.biomedcentral.com/track/pdf/10.1186/s12985-015-0291-7>. doi: 10.1186/s12985-015-0291-7

DENG, X.; QI, X.; GAO, Y.; WANG, Y.; QIN, L. et al. Development of a loopmediated isothermal amplification method for rapid detection of reticuloendotheliosis virus. Journal of virological methods, v. 168, n. 1, p. 82-86, 2010. Disponível em: <https://doi.org/10.1016/j.jviromet.2010.04.021 >. doi: 10.1016/j.jviromet.2010.04.021

GAO, Q.; YUN, B.; WANG, Q.; JIANG, L.; ZHU, H. et al. Development and application of a multiplex PCR method for rapid differential detection of subgroup A, $\mathrm{B}$, and $\mathrm{J}$ avian leukosis viruses. Journal of clinical microbiology, v. 52, n. 1, p. 3744, 2014. Disponível em: <https://jcm.asm.org/content/jcm/52/1/37.full.pdf>. doi: 10.1128/JCM.02200-13

GOPAL, S.; MANOHARAN, P.; KATHAPERUMAL, K.; CHIDAMBARAM, B.; DIVYA, K. C. Differential detection of avian oncogenic viruses in poultry layer farms and turkeys by use of multiplex PCR. Journal of clinical microbiology, v. 50, n. 8, p. 2668-2673, $2012 . \quad$ Disponível em:

https://jcm.asm.org/content/jcm/50/8/2668.full.pdf>. doi:10.1128/JCM.00457-12

HÄUPTLI, D.; BRUCKNER, L.; OTTIGER, H. Use of reverse transcriptase polymerase chain reaction for detection of vaccine contamination by avian leukosis virus. Journal of virological methods, v. 66, n. 1, p. 71-81, 1997. Disponível em: < https://doi.org/10.1016/S0166-0934(97)02213-1>. doi: https://doi.org/10.1016/S01660934(97)02213-1

HOY, M. A. An introduction to Principles and Applications. San Diego : Academic Press, 546 p. p. $203-245,1994$.

ICTV - International Committee on Taxonomy of Viruses. 2015. Disponível em: < https://talk.ictvonline.org/taxonomy/p/taxonomy-

history?taxnode_id=20164210\&taxa_name=Avian\%20leukosis\%20virus > .

OTTIGER, H. Development, standardization and assessment of PCR systems for purity testing of avian viral vaccines. Biologicals, v. 38, n. 3, p. 381-388, 2010. Disponível em: <https://doi.org/10.1016/j.biologicals.2010.01.015>. doi: 10.1016/j.biologicals.2010.01.015

PAYNE, L. N.; NAIR, V. The long view: 40 years of avian leukosis research. Avian Pathology, v. 41, n. 1, p. 11-19, 2012. Disponível em: <http://dx.doi.org/10.1080/03079457.2011.646237>. doi: $10.1080 / 03079457.2011 .646237$ 
QIAN, K.; LIANG, Y. Z.; YIN, L. P.; SHAO, H. X.; YE, J. Q. et al. Development and evaluation of an immunochromatographic strip for rapid detection of capsid protein antigen p27 of avian leukosis virus. Journal of virological methods, v. 221, p. 115118, 2015. Disponível em: <https://doi.org/10.1016/j.jviromet.2015.04.033>. doi: 10.1016/j.jviromet.2015.04.033

RAJABZADEH, M.; DADRAS, H.; MOHAMMADI, A. Detection of avian leukosis virus subgroups in albumen of commercial and native fowl eggs using RT-PCR in Iran. Tropical animal health and production, v. 42, n. 8, p. 1829-1836, 2010. Disponível em: < https://link.springer.com/article/10.1007\%2Fs11250-010-9645-8>. doi: 10.1007/s11250-010-9645-8

SARAIVA, A. C. M. Prevalência do Papilomavírus Humano na região do Triângulo Mineiro diagnosticada por meio da Reação em Cadeia de Polimerase. Uberlândia, 1999. p. 11-12. Monografia apresentada à Coordenação do curso de Ciências Biológicas da Universidade Federal de Uberlândia para a obtenção do grau de bacharel em Ciências Biológicas.

SILVA, R. F.; FADLY, A. M.; TAYLOR, S. P. Development of a polymerase chain reaction to differentiate avian leukosis virus (ALV) subgroups: detection of an ALV contaminant in commercial Marek's disease vaccines. Avian diseases, v. 51, n. 3, p. 663-667, 2007. Disponível em: <https://doi.org/10.1637/00052086(2007)51[663:DOAPCR]2.0.CO;2>. doi: 10.1637/00052086(2007)51[663:DOAPCR]2.0.CO;2

SMITH, L. M.; BROWN, S. R.; HOWES, K.; McLEOD, S.; ARSHAD, S. S. et al. Development and Application of polymerase chain reaction (PCR) tests for the detection of subgroup $\mathrm{J}$ avian leukosis virus. Virus Res, n. 54, p. 87-98, 1998. Disponível em: <https://doi.org/10.1016/S0168-1702(98)00022-7>. doi 10.1016/S0168-1702(98)00022-7

WANG, X.; ZHAO, P.; CUI, Z. Z. Identification of a new subgroup of avian leukosis virus isolated from Chinese indigenous chicken breeds. Bing Du Xue Bao, v. 28, n. 6, $\quad$ p. $609-614,2012$ Disponível em: < https://www.ncbi.nlm.nih.gov/pubmed/23367558>.

YUN, B.; LI, D.; ZHU, H.; LIU, W.; QIN, L. et al. Development of an antigen-capture ELISA for the detection of avian leukosis virus p27 antigen. Journal of virological methods, v. 187, n. 2, p. 278-283, 2013. Disponível em: <https://doi.org/10.1016/j.jviromet.2012.11.027>. doi:10.1016/j.jviromet.2012.11.027

ZAVALA, G.; JACKWOOD, M. W.; HILT, D. A. Polymerase chain reaction for detection of avian leukosis virus subgroup $\mathrm{J}$ in feather pulp. Avian diseases, v. 46, n. 4, p. 971-978, 2002. Disponível em: <https://doi.org/10.1637/00052086(2002)046[0971:PCRFDO]2.0.CO;2>. doi: 10.1637/00052086(2002)046[0971:PCRFDO]2.0.CO;2 